\title{
EFEKTIVITAS MODEL PEMBELAJARAN CONTEXTUAL TEACHING LEARNING DAN MEDIA AUDIO VISUAL DALAM MENINGKATKAN MOTIVASI, MINAT DAN HASIL BELAJAR PESERTA DIDIK KELAS VI SDIT TAMAN ILMU KOTA DEPOK MATA PELAJARAN PELAJARAN IPA DENGAN TEMA CIRI KHUSUS HEWAN DAN TUMBUHAN
}

\author{
Yuliana Susanti \\ Universitas Terbuka \\ NIM. 836387516 \\ Email : annasusanto18@gmail.com
}

\begin{abstract}
ABSTRAK
Penelitian ini dlaksanakan berawal dari keprihatinan penulis terhadap hasil belajar peserta didik kelas VI Sdit Taman Ilmu pada mata pelajaran IPA dengan tema Ciri khusus Hewan dan Tumbuhan. Pada pembelajaran yang terjadi di tahap prasiklus, metode yang digunakan penulis yaitu metode ceramah. Hasil evaluasi peserta didik yang diukur dengan penilaian menunjukan nilai dibawah KKM dengan nilai rata - rata 55,95 dengan hasil ketuntasan hanya $24 \%$ dan hanya $5 \%$ peserta didik yang dapat menjawab pertanyaan dari guru. Pada siklus 1, penulis menggunakan model pembelajaran Contextual Teaching Learning (CTL) dan media berupa gambar. Hasil evaluasi peserta didik mengalami kemajuan dengan rata - rata kelas menjadi 69,01 dengan hasil ketuntasan sebesar 52\%. Dari hasil pengamatan penulis terhadap peserta didik yang mampu menjawab pertanyaan guru juga mengalami kenaikan yaitu sebesar $62 \%$. Pada siklus 2 selain menggunakan media gambar penulis juga menambahakan media berupa video pembelajran (Audiovisual) yang. Terjadi peningkatan yang cukup signifikan terhadap hasil belajar peserta didik. Hal ini ditandai dengan peningkatan hasil belajar peserta didik dengan nilai rata - rata 86,67 dan prosentase ketuntasan sebesar $81 \%$. Adapun prosentase peserta didik yang mampu menjawab pertanyaan yang diberikan sebesar $81 \%$. Penerapan model pembelajaran Contextual Teaching Learning dengan menggunakan media pembelajaran berupa media gambar dan media Audiovisual memberikan pengaruh yang sangat positif pada hasil belajar peserta didik. Penggunaan model ini juga dapat membangun kreativitas dan keaktifan peserta didik pada proses pembelajaran.
\end{abstract}

Kata kunci : Contextual Teaching Learning, audio visual, dan IPA

\section{PENDAHULUAN}

\section{A. Latar Belakang Masalah}

Pembelajaran IPA menjadi salah satu pelajaran utama di jenjang sekolah dasar. Karena peserta didik masih memiliki kecenderungan berpikir konkrit penyampaian pembelajaran IPA seharusnya tidak memiliki kendala yang berarti. Hal ini disebabkan karena pelajaran IPA sebenarnya lebih banyak 
berhubungan dengan keseharian peserta didik termasuk juga lingkungan sekitar peserta didik . Jadi dalam penyampaiannya hendaknya tidak hanya berorientasi pada teori dan hafalan melainkan lebih mengajak kepada peserta didik agar dapat berpikir ilmiah dan kerja ilmiah dengan melihat, praktek langsung dan mengaplikasikan kepada lingkungan dan kehidupan peserta didik sehari -hari.

Metode pembelajaran di sekolah terkadang membuat anak bosan dan tidak menyenangkan, apalagi pada pelajaran IPA dengan metode yang tidak variatif sering kali peserta didik mendapatkan nilai dibawah KKM yang ditentukan sehingga dalam pelajaran sehari - hari anak akhirnya kurang tertarik, kurang latihan ataupun kurang membaca, dan akhirnya berdampak pada perolehan pemahaman dan nilai tidak optimal. Sehingga perlu sekali diberikan upaya pembelajaran yang menyenangkan dan mengedepankan peserta didik aktif, sehingga semua peserta didik akan termotifasi untuk belajar lebih semangat dan senang.

Permasalahan ini pulalah yang terjadi terhadap peserta didik kelas VI SDIT Taman ilmu kota Depok. Berdasarkan hasil pengamatan yang dilakukan penulis setelah penulis melakukan proses pembelajaran pada tahap prasiklus,masih terdapat banyak kekurangan terutama pada tokoh sentral yaitu guru. Hal tersebut ditandai dengan hasil belajar peserta didik kelas VI SDIT Taman Ilmu yang terdiri dari 21 peserta didik hanya 5 peserta didik yang mendapat nilai diatas KKM sehingga menyebabkan nilai rata- rata kelasnya masih dibawah KKM dengan nilai 55,95. Hal ini disebabkan karena guru belum menggunakan model dan media yang tepat ketika mengajar.

Prihatin dengan masalah tersebut maka penulis memutuskan untuk melakukan perbaikan pengajaran dengan menambahkan model dan media yang sesuai yang dapat membangkitkan motivasi serta minat belajar peserta didik, sehingga nilai rata- rata kelas bisa mencapai KKM atau melampaui KKM

\section{Identifikasi Masalah}


Berdasarkan atas latar belakang masalah yang penulis uraikan diatas dan hasil komunikasi dengan teman sejawat mengenai pembelajaran yang telah dilaksanakan terdapat beberapa masalah antara lain :

a. Peserta didik yang memperoleh nilai diatas KKM hanya 5 orang dari jumlah peserta didik 21 orang

b. Peserta didik kurang aktif dalam proses pembelajaran

c. Motivasi belajar yang kurang pada diri peserta didik

d. Tidak semua peserta didik yang mampu menjawab pertanyaan yang dilontarkan guru

e. Peserta didik kurang fokus saat pembelajaran berlangsung

\section{Analisis Masalah}

Berdasarkan latar belakang masalah diatas maka ditemukannya penyebab rendahnya hasil belajar peserta didik di kelas VI Sdit Taman Ilmu Kota Depok adalah :

a. Peserta didik yang mencapai penguasaan materi lebih dari 50\% hanya 5 orang dari 21 peserta didik .

b. Metode pembelajaran yang digunakan kurang tepat/tidak sesuai.

c. Tidak adanya media pendukung dalam proses pembelajaran sehingga peserta didik merasa jenuh.

d. Kurangnya motivasi yang diberikan oleh guru sehingga peserta didik menjadi tidak bersemangat

e. Guru hanya melakukan komunikasi satu arah sehingga tidak terciptanya umpan balik antara guru dan peserta didik yang menyebabkan peserta didik pada akhirnya tidak merespon materi yang diajarkan

\section{Alternatif dan Prioritas Pemecahan Masalah}

Berdasarkan latar belakang masalah, penulis memprioritaskan alternatif pemecahan masalah antara lain :

a. Penggunaan media dan model pembelajaran harus dapat memberikan motivasi kepada peserta didik sehingga peserta didik mau dan mampu meningkatkan hasil belajarnya.

b. Penggunaan media dan model Pembelajaran dapat disesuaikan dengan materi yang dipelajari sehingga tidak menyebabkan kejenuhan bagi peserta didik .

c. Penggunaan media dan metode pembelajaran harus dapat menarik perhatian peserta didik dan memancing kreatifitas peserta didik 
sehingga akan tercipta pembelajaran yang menyenangkan, aktif dan kreatif.

d. Penggunaan media dan metode pembelajaran harus dapat menciptakan komunikasi dua arah antara guru dan peserta didik juga peserta didik dan peserta didik sehingga proses pembelajaran dapat berjalan lebih maksimal.

\section{B. Rumusan Masalah}

Adapun rumusan masalah yang dapat penulis simpulkan adalah "Bagaimana meningkatkan hasil belajar peserta didik dan kualitas pembelajaran IPA melalui pendekatan Contextual Teaching and Learning (CTL) dan penggunaan Media Audiovisual pada peserta didik kelas VI SDIT Taman Ilmu Kota Depok?.”

\section{Tujuan Penelitian}

Berdasarkan uraian dari rumusan masalah setiap kegiatan penelitian yang dilakukan adalah untuk meningkatkan hasil belajar peserta didik dan kualitas pembelajaran IPA melalui pendekatan Contextual Teaching and Learning (CTL) dan penggunaan Media Audio visual pada peserta didik kelas VI SDIT Taman Ilmu Kota Depok?

Tujuan Penelitian Perbaikan Pembelajaran dapat diuraikan sebagai berikut:

\section{Bagi Peserta didik}

a. Untuk meningkatkan hasil belajar peserta didik dan kualitas pembelajaran IPA melalui pendekatan Contextual Teaching and Learning (CTL) pada peserta didik kelas VI SDIT Taman Ilmu Kota Depok

b. meningkatkan hasil belajar peserta didik dan kualitas pembelajaran IPA melalui penggunaan Media Audio visual pada peserta didik kelas VI SDIT Taman Ilmu Kota Depok

c. Meningkatkan keaktifan peserta didik dan kualitas pembelajaran IPA melalui pendekatan Contextual Teaching and Learning (CTL) dan penggunaan media audio visual pada peserta didik kelas VI SDIT Taman Ilmu Kota Depok

\section{Bagi Guru}


a. Meningkatkan kinerja guru dalam menerapkan metode yang lebih bervariasi dan menggunakan media pembelajaran dalam Pelajaran IPA

b. Untuk mengetahui penyebab peserta didik yang tidak mampu memahami materi Pelajaran IPA

c. Untuk meningkatkan kreatifitas guru dalam melaksanakan pembelajaran Pelajaran IPA

d. Untuk Mengetahui sejauh mana pengaruh penggunaan Contextual Teaching and Learning (CTL) dan penggunaan media audio visual dalam pembelajaran

\section{Manfaat Penelitian}

Manfaat penelitian perbaikan pembelajaran di susun dalam rangka peningkatan mutu pendidikan dan memberikan manfaat yang positif bagi berbagai pihak :

1. Manfaat Bagi Peserta didik :

a. Meningkatkan hasil belajar peserta didik terutama dalam pelajaran IPA

b. Memotivasi peserta didik serta menumbuhkan minat peserta didik dalam pelajaran IPA

c. Meningkatkan ketrampilan bertanya bagi peserta didik

d. Mampu memahami konsep konsep pelajaran IPA dengan penggunaan media Audiovisual

e. Melatih peserta didik agar lebih mandiri dalam hal belajar

2. Manfaat Bagi Guru :

a. Membantu guru memperbaiki pembelajaran.

b. Membantu guru berkembang secara profesional.

c. Merangsang guru untuk lebih kreatif dengan menemukan inovasi baru dalam pembelajaran sehingga tercipta suasana yang aktif dan kreatif serta menyenangkan.

d. Meningkatkan rasa percaya diri guru.

e. Membantu guru mengembangkan pengetahuan dan ketrampilannya.

3. Manfaat bagi sekolah :

a. Sekolah menjadi lebih maju karena guru - guru yang inovatif secara tidak langsung akan meningkatakan kualitas pendidikan

b. Menjadi nilai jual tersendiri bagi sekolah karena metode pembelajaran yang menyenangkan akan membuat peserta didik lebih kreatif dan mandiri. 
4. Manfaat bagi Masyarakat :

a. Hasil penelitian ini dapat digunakan oleh sekolah - sekolah lain yang mungkin menghadapi permasalahan yang sama dalam proses pembelajaran di sekolahnya.

b. Dapat digunakan sebagai referensi bagi peneliti berikutnya.

\section{KAJIAN PUSTAKA}

\section{A. Hakekat Hasil Belajar IPA di SD}

\section{Hakekat Hasil Belajar}

Menurut Anitah (2014 : 2.5) belajar adalah suatu usaha yang dilakukan individu untuk memperoleh suatu perubahan tingkah laku yang baru, secara keseluruhan sebagai pengalaman individu itu sendiri dalam berinteraksi dengan lingkungannya. Demikian pula yang disampaikan Bruner dalam Sapriati (2014 : 1.23) belajar merupakan suatu kegiatan pengolahan informasi yang menemukan kebutuhan-kebutuhan untuk mengenal dan menjelaskan gejala yang ada di lingkungan kita.

Sedangkan menurut Gagne dalam Anitah (2014 : 1.3) belajar adalah suatu proses dimana suatu organisme berubah perilakunya sebagai akibat pengalaman. Dimyati dan Mudjiono (2008 : 3) menyatakan bahwa hasil belajar merupakan hasil dari interaksi tindakan belajar dan tindakan mengajar dan dari sisi guru, tindakan diakhiri dengan proses evaluasi hasil belajar sedangkan dari Peserta didik, hasil belajar merupakan berkhirnnya pengalaman belajar. Sementara itu, Oemar Hamalik (2008 : 36) mengatakan bahwa "hasil belajar bukan suatu penguasaan hasil latihan, melainkan perubahan kelakuan”.

Untuk mengetahui hasil belajar seseorang dapat dilakukan dengan melakukan tes dan pengukuran. Tes dan pengukuran memerlukan alat sebagai pengumpul data yang disebut dengan instrumen penilaian hasil belajar. Menurut Wahidmurni, (2010 : 28) instrumen dibagi menjadi dua bagian besar, yakni tes dan non tes. Selanjutnya, menurut Hamalik (200 6: 155), memberikan gambaran bahwa hasil belajar yang diperoleh dapat diukur melalui kemajuan yang diperoleh peserta didik setelah belajar 
dengan sungguh-sungguh. Hasil belajar tampak terjadinya perubahan tingkah laku pada diri peserta didik yang dapat diamati dan diukur melalui perubahan sikap dan keterampilan. Perubahan tersebut dapat diartikan terjadinya peningkatan dan pengembangan yang lebih baik dibandingkan dengan sebelumnya.

Melalui uraian para ahli diatas dapat dikatakan bahwa hasil belajar merupakan puncak kulminasi dari proses belajar mengajar. Dalam proses belajar ini di dalamnya terdapat proses pemasukan berupa informasi. Outputs yang diperoleh berupa perubahan tingkah laku atau perilaku yang baru yang bersifat positif dan disadari. Kualitas hasil belajar dapat dilihat dari hasil pengukuran berupa evaluasi

\section{Hakekat Mata Pelajaran IPA di SD}

Dalam lampiran Permendikbud nomer 58 tahun 2014 dinyatakan bahwa IPA sebagai mata pelajaran, diberikan mulai dari jenjang sekolah dasar sampai jenjang menengah sekolah atas.Pada level SD kelas 1, 2, dan 3 muatan IPA diintegrasikan pada kompetensi dasar mata pelajaran Bahsa Indonesia.Di kelas 4 sampai dengan kelas 6 IPA menjadi mata pelajaran tersendiri tetapi pembelajarannya melalui pembelajran tematik terpadu.

Masih menurut Jufri (2014:123) pendidikan sains di Sekolah dasar dan menengah memeiliki tiga tujuan umum yaitu :

1. Mempersiapkan siswa mempelajari Sains pada tingkat pendidikan yang lebih tinggi

2. Mempersiapkan siswa untuk memasuki tantangna dunia kerja atau menjalankan tugas sesuai dengan bidang kerjanya.

3. Mempersiapkan siswa untuk menjadi anggota masyarakat yang melek sains.

Dari semua pendapat para ahli diatas tentang pendidikan sains di sekolah dasar dapat disimpulkan bahwa pendidikan sains merupakan salah satu pendidikan pokok yang diajarakan di sekolah dasar yang menjadi dasar bagi siswa di jenjang pendidikan selanjutnya. Oleh sebab itu pendidikan sains hendaknya lebih bersifat praktek dan dihubungkan dengan kehidupan seharihari sehingga ingatan siswa akan pengetahuan yang dimilikinya disekolah 
dasar dapat berlangsung lama dan dapat digunakan lagi dijenjang pendidikan selanjutnya. Sehingga mata pelajara ilmu pengetahuan alam merupakan pendidikan yang bertujuan untuk membentuk peserta didik memiliki sikap ilmiah dan dapat menjadi warga Negara yang bermoral serta tanggap terhadap masalah lingkunganya

\section{B. Model Pembelajaran Contextual Teaching Learning}

Menurut sanjaya (2006 : 255) Contextual Teaching Learning adalah suatu strategi pembelajaran yang menekankan pada proses keterlibatan siswa secara penuh untuk dapat menemukan materi yang dipelajari dan menghubungkannya dengan situasi kehidupan nyata sehingga mendorong siswa untuk dapat menerapkan dalam kehidupan mereka.

Masih menurut Sanjaya (2006:255) ada 3 hal yang harus dipahami dalam model pembelajaran Contextual Teaching Learning yaitu :

1. CTL menekankan kepada proses keterlibatan siswa untuk menemukan materi artinya proses belajar diorientasikan pada proses pengalaman secara langsung.

2. CTL mendorong agar siswa dapat menemukan hubungan anatar materi yang dipelajarai dengan situasi kehidupan nyata, artinya siswa dituntut untuk dapat menagkap hubungan antara pengalaman belajarv di sekolah dengan kehidupan nyata.

3. CTL mendorong siswa untuk dapat menerapkannya dalam kehidupan artinya CTL bukan hanya mengharapkan siswa dapat memahami materi yang dipelajari, akan tetapi bagaimana materi pelajaran itu dapat mewarnai perilakunya dalam kehidupan sehari-hari.

Dari pengertian diatas dapat diambil kesimpulan bahwa model pembelajaran Contextual Teaching learning adalah model pembelajaran yang menekankan keterlibatan siswa untuk aktif dan kreatif dalam pembelajaran.metode ini juga mengajak siswa untuk menghunbungkan kejadian yang terjadi ataupun fakta yang terjadi di lapangan dengan materi yang diterima sehingga materi pelajaran bukan hanya sekedar hafalan dari sebuah teori semata. 


\section{Media Pembelajaran Audiovisual}

Media merupakam alat atau wadah yang dapat digunakan. Ada beberapa pengertian media pembelajaran yang disampaikan oleh par ahli antara lain : menurut Rossie dan Breidle (1966) dalam Sanjaya (2006 : 163) media pembelajaran adalah seluruh alat dan bahan yang dapat dipakai untuk mencapai tujuan pendidikan.sedangkan menurut Gerlach dan Ely (1980) dalam sanjaya (2006:163) secara umum media meliputi orang, bahan, peralatan, kegiatan yang menciptakan kondisi yang memungkinkan siswa memperoleh pengetahuan,keterampilan, dan sikap.

Dari pengertian media audiovisual diatas penulis dapat mengambil kesempulan bahwa media audiovisual adalah jenis media pembelajaran yang paling komplit dimana ada perpaduan media audio dan visual. Dalam beberapa kasus atau kegiatan peran media Audiovisual ini dapat menggantikan peran guru dalam menyampaikan materi pembelajaran sehingga guru dapat berperan sebagai fasilitator. Meskipun demikian ada beberapa faktor yang perlu diperhatikan agar penggunaan media audiovisual benar dan tepat sasaran sehingga pesan yang akan disampaikan dapat tersampaikan dengan baik kepada peserta didik.

\section{PELAKSANAAN PENELITIAN PERBAIKAN PEMBELAJARAN}

\section{A. Subjek, Tempat dan Waktu Penelitian, Pihak yang Membantu}

\section{Subjek dan Tempat Penelitian}

Subjek dan Tempat Penelitian yang digunakan oleh penulis untuk melakukan Penelitian Tindakan Kelas adalah SDIT Taman Ilmu, Yang beralamat di Jalan Raden Sanim Rt.007/RW.002 No.144 Kelurahan Tanah Baru, Kecamatan Beji, Kota Depok. Telepon 02177801895.

\section{Waktu Penelitian}

Waktu pelaksanaan penelitian tindakan kelas dilaksanakan mulai tanggal 16 Agustus 2017, diawali dengan kegiatan prasiklus awal ketika pertama kali permasalahan ditemui.Kemudian dilanjutkan perbaikan pembelajaran dengan siklus 1 pada tanggal 23 Agustus 2017, pada siklus ini masih ditemui peserta didik yang mendapat nilai di bawah KKM. 
Selanjutnya diadakan kembali perbaikan pembelajaran pada siklus 2 yang dilaksanakan pada tanggal 30 Agustus 2017.

\section{Pihak Yang Membantu Penelitian}

1. Ibu Yuliana Susanti, SE selaku Kepala Sekolah

2. Bapak Drs.Imam Subekti selaku teman sejawat

\section{B. Desain Prosedur Perbaikan Pembelajaran}

Setelah penulis menemukan adanya permasalahan dari hasil pembelajaran peserta didik, penulis kemudian membuat perencanaan perbaikan pembelajaran yang akan digunakan dalam penelitian tindakan kelas dengan tema "Ciri Khusus Hewan dan Tumbuhan", pada mata pelajaran Ilmu Pengetahuan Alam ( IPA).

Penulis melakukan tindakan penelitian yang dibagi ke dalam 2 siklus, dimana setiap siklus melalui empat tahapan, yaitu tahap perencanaan, pelaksanaan, pengamatan dan refleksi. Penulis mendeskripsikan pelaksanaan penelitian sebagai berikut ;

1. Siklus 1

a. Perencanaan

1. Penulis melaksanakan refleksi diri dan mengidentifikasi hasil pembelajaran prasiklus untuk selanjutnya membuat rencana perbaikan pembelajaran.

2. Menyusun RPP dengan menggunakan model pembelajaran Contextual Teaching Learning (CTL)

3. Menambahkan media gambar hewan dan tumbuhan yang memiliki ciri - cirri khusus.

4. Membuat alat evaluasi yang sesuai

b. Pelaksanaan

1. Kegiatan Awal

a. Guru mengucapkan salam,meminta salah seorang peserta didik memimpin doa,mengabsen kehadiran peserta didik dan menyiapkan alat pembelajaran.

b. Guru meminta peserta didik menjaga ketertiban selama pelajaran berlangsung

c. Guru membagi peserta didik ke dalam 4 kelompok 
d. Guru membangun semangat peserta didik dengan menyanyikan lagu pembangkit semangat

e. Guru menyampaikan topik yang akan dipelajari

f. Guru menyampaikan tujuan pembelajaran

2. Kegiatan Inti

a) Eksplorasi

1. Guru menuliskan di papan topik yang akan dipelajari

2. Guru menempelkan gambar hewan di papan tulis dan meminta siswa untuk menyebutkan nama hewan atau tumbuhan yang mereka lihat dan menyebutkan ciri - ciri apa yang nampak dari gambar tersebut

3. Guru menambahkan ciri khusus hewan dan tumbuhan yang belum disebutkan peserta didik Peserta didik memperhatikan penjelasan guru tentang ciri khusus hewan dan tumbuhan

b) Elaborasi

1. Guru memberikan kertas kerja kepada peserta didik dan memeinta peserta didik mengerjakan soal tersebut secara berkelompok

2. Guru didik untuk membaca buku selain buku teks yang dipelajari

3. Guru memberi kesimpulan dari materi yang telah dipelajari

c) Konfirmasi

2. melakukan tanya jawab seputar materi yang telah dipelajari.

3. Guru memberikan acuan kepada peserta didik untuk membaca buku selain buku teks yang dipelajari

4. Guru memberi kesimpulan dari materi yang telah dipelajari

3. Kegiatan Akhir

a. Guru memberikan tes akhir pembelajaran

b. Peserta didik diminta mengerjakan soal tes akhir pembelajaran dalam waktu 10 menit 
c. Guru bersama peserta didik memeriksa soal evaluasi dengan sistem silang

d. Guru menutup pelajaran dengan mengajak peserta didik mengucapkan Hamdalah

e. Guru mengucapkan salam

c. Pengamatan

Berdasarkan hasil pengamatan dan observasi yang dilakukan oleh penulis pada saaat mengajar pada siklus 1 maka, diperoleh permasalahan sebagai berikut :

1. Model pembelajaran yang digunakan sudah bervariatif dengan menggunakan model pembelajaran berkelompok dan model Contextual Teaching Learning (CTL).

2. Guru sudah mulai melakukan komunikasi 2 arah dengan memancing pendapat peserta didik tentang gambar yang disampaikan

3. Media pembelajaran yang digunakan belum dapat menarik perhatian siswa

d. Refleksi

Dari hasil pembelajaran yang terdapat pada siklus 1, penulis menemukan adanya kelemahan dan kekuatan dalam tindakan perbaikan pembelajaran yang telah dilakukan. Adapun kekuatan dan kelemahan dari perbaikan pembelajaran adalah sebagai berikut :

1. Kekuatan

a. Peserta ddidk terlihat sudah mulai antusias

b. Peserta didik sudah mulai mempunyai motivasi dalam belajar walaupun untuk beberapa anak masih terlihat sama seperti di siklus sebelumnya.

c. Komunikasi 2 arah sudah mulai tercipta sehingga siswa dapat ikut berperan aktif dalam proses pembelajaran

d. Peserta didik mempunyai pengalaman baru karena penulis sudah mulai menggunakan model pembelajaran yanmg berbeda dari 
siklus sebelumya walaupun model yang digunakan belum maksimal.

2. Kelemahan

1. Peserta didik masih ada yang mendapat nilai di bawah KKM,dengan nilai rata - rata 74,29

2. Media yang digunakan belum bervariasi dan belum menarik minat siswa.

\section{Siklus 2}

a. Perencanaan

Pada tahap ini penulis membuat rencana perbaikan pembelajaran berdasarkan refleksi dari siklus 1 untuk mencapai pembelajaran yang lebih baik.Berikut persiapan pembelajaran pada siklus 2 :

1. Menentukan tujuan perbaikan pembelajaran

2. Menyusun perangkat pembelajaran dengan menggunakan model Contextual Teaching Learning (CTL)

3. Menyiapkan gambar hewan dan tumbuhan yang memiliki cirri khusus

4. Menambahkan Video Pembelajaran tentang Ciri Khusus hewan dan tumbuhan

5. Membuat alat evaluasi

b. Pelaksanaan

1. Kegiatan Awal

a. Guru mengucapkan salam,meminta salah seorang peserta didik memimpin doa,mengabsen kehadiran peserta didik dan menyiapkan alat pembelajaran.

b. Guru meminta peserta didik menjaga ketertiban selama pelajaran berlangsung

c. Guru membagi siswa kedalam 4 kelompok.

d. Guru membangun semangat peserta didik dengan mengajak peserta didik untuk melakukan tepuk sdit Taman Ilmuu

e. Guru meminta 2 orang peserta didik dengan ukuran dan jenis kelamin yang berbeda untuk maju ke depan dan meminta peserta didik yang lain untuk menyebutkan apa yang mereka lihat dari kedua temannya tersebut. 
f. Guru menyampaikan topik yang akan dipelajari

g. Guru menyampaikan tujuan pembelajaran

2. Kegiatan Inti

a) Eksplorasi

1. Guru menuliskan di papan topik yang akan dipelajari

2. Guru menampilkan gambar hewan dan tumbuhan yang ada dan pernah dijumpai dalam kehidupan sehari hari

3. Guru meminta pesrta didik menjelaskan apa yang mereka lihat pada gambar tersebut.

4. Guru menambahkan beberapa informasi mengenai hewan dan tumbuhan yang ditampilkan pada gambar guna memberi pengetahuan baru bagi peserta didik

5. Guru memutarkan video tentang cirri cirri khusus hewan dan tumbuhan agar siswa lebih paham tentang materi yang diberikan.

b) Elaborasi

1. Guru membagikan lembar kerja kepada peserta didik dan meminta mereka untuk melengkapi gambar tersebut dengan cirri khusus yang dimiliki oleh hewan ataupun tumbuhan.

2. Setelah selesai mengerjakan peserta didik diminta untuk mempresentasikan hasil pekerjaan masing masing kelompok.

a) Konfirmasi

1. Guru melakukan tanya jawab seputar materi yang telah dipelajari.

2. Guru memberikan acuan kepada peserta didik untuk membaca buku selain buku teks yang dipelajari

3. Guru memberi kesimpulan dari materi yang telah dipelajari

3. Kegiatan Akhir (15 menit)

1. Peserta didik mengerjakan soal evaluasi

2. Guru menutup pelajaran dengan mengajak peserta didik mengucapkan Hamdalah 


\section{Guru mengucapkan salam}

\section{c. Pengamatan}

Selain melakukan kegiatan perbaikan pembelajaran penulis juga melakukan pengamatan terhadap peserta didik. Dari hasil pengamatan tersebut penulis dapat mengambil kesimpulan bahwa dengan memaksimalkan penggunaan model pembelajaran berupa Contextual Teaching Learning ( CTL ) disertai penggunaan media Audiovisual terlihat perubahan yang cukup signifikan selama proses pembelajaran dan hasil belajar yang diperoleh peserta didik.

Hal ini ditandai dengan adanya peningkatan nilai rata- rata kelas pada tiap siklus pembelajaran. Pada siklus 1 nilain rata - rata yang diperoleh peserta didik kelas VI adalah 74,29. Sedangkan nilai rata - rata peserta didik pada siklus 2 adalah 85,95.

Dari hasil pengamatan penulis juga ditemukan bahwa tidak hanya nilai rata - rata kelas yang meningkat tetapi juga motivasi dan minat siswa terhadap pembelajran ikut meningkat. Menurut penulis hal itu disebabkan karena penggunaan model pembelajran Contextual Teaching Learning ( CTL ) secara maksimal dan juga dibantu dengan media audiovisual mampu merubah suasana pembelajaran menjadi efektif dan menyenangkan bagi siswa.

d. Refleksi

Setelah penulis mengadakan kegiatan perbaikan pembelajaran, penulis dibantu oleh teman sejawat melakukan refleksi terhadap kegiatan perbaikan pembelajaran yang telah dilewati.Terdapat beberapa hal yang menjadi point penting setelah penulis memutuskan untuk melakukan perbaikan kegiatan pembelajaran dengan menggunakan model Contextual Teaching Learning ( CTL ) yaitu :

1. Dengan menggunakan model Contextual Teaching Learning ( CTL ) peserta didik lebih mudah memahami materi ciri khusus hewan dan tumbuhan. 
2. Dengan Menggunakan model Contextual Teaching Learning ( CTL ) memancing peserta didik untuk lebih kreatif dalam menemukan jawaban dari sebuah pertanyaan

3. Penggunaan media Audiovisual mampu meningkatkan motivasi dan minat peserta didik dalam mempelajari tema ciri khusus hewan dan tumbuhan

4. Pembelajaran secara berkelompok membuat peserta didik lebih kompak karena mereka harus bekerja sama untuk menyelesaikan soal

5. Peserta didik mendapatkan pengalaman belajar yang menyenangkan.

6. Hasil evaluasi pembelajaran cukup memuaskan.

\section{Teknik Analisis Data}

Dalam melakukan analisis data peneliti memulai dengan melakukan pengumpulan data pada setiap kegiatan observasi dimulai dengan pelaksanaan kegiatan prasiklus, dianalisis dengan deskriptif kualitatif, dimana penulis menggunakan presentase untuk melihat hasil dalam setiap proses pembelajaran pada mata pelajaran Ilmu Pengetahuan Alam dengan materi "Ciri Khusus Hewan dan Tumbuhan “

Adapun langkah - langkah yang digunakan oeh penulis dalam teknik analisis data adalah sebagai berikut :

1. Melaksanakan proses kegiatan belajar mengajar.

2. Mengumpulkan nilai hasil evaluasi pembelajaran.

3. Mendeskripsikan dan membandingkan tiap - tiap siklus yang dilakukan oleh penulis.

4. Menentukan tingkat keberhasilan dari hasil evaluasi yang akan ditempuh dalam setiap proses pembelajaran yang dilaksanakan.

\section{HASIL DAN PEMBAHASAN}

\section{A. Deskripsi Penelitian dan Perbaikan Pembelajaran}

Dalam pelaksanaan penelitian tindakan kelas penulis yang dibantu oleh teman sejawat telah melakukan observasi. Banyak masukan yang penulis peroleh dari teman sejawat yang berkaitan dengan kegiatan proses pembelajaran yang telah dilaksanakan.Diskusipun dilakukan guna mencari dan 
menemukan kekurangan baik dari peserta didik maupun kekurangan pada guru sebagai pengajar.Tidak hanya sampai disitu, penulis dibantu teman sejawat juga mencari cara agar proses pembelajaran dapat berjalan dengan baik dan hasil pembelajaran dapat sesuai harapan yaitu minimal sama dengan KKM atau melebihi KKM.

Setelah melakukan observasi bersama teman sejawat, penulis juga melakukan refleksi diri pada proses pembelajaran yang telah di jalani guna menentukan langkah - langkah apa yang harus ditempuh untuk memperbaiki proses pembelajaran. Hasil refleksi yang telah dilaksanakan oleh penulis adalah sebagai berikut :

1. Motivasi dari peserta didik yang masih kurang.

2. Nilai rata - rata kelas yang masih dibawah KKM.

3. Peserta didik tidak terlibat aktif dalam proses pembelajaran karena komunikasi yang diciptakan guru hanya satu arah.

4. Kurangnya kreativitas penulis sebagai pengajar dalam menggunakan metode ataupun model pembelajaran.

Pada proses pembelajaran prasiklus ,penulis menggunakan metode ceramah dan tidak menggunakan media serta model pembelajaran.Sehingga menyebabkan proses pembelajaran di tahap prasiklus menjadi monoton dan membosankan bagi siswa. Hal ini tentu saja berdampak pada banyaknya peserta didik yang memperoleh hasil evaluasi akhir pembelajaran berada di bawah KKM. Ada beberapa permasalahan yang ditemukan oleh penulis dari tahap prasiklus yang dilewati antara lain :

1. Siswa yang mencapai penguasaan materi lebih dari $50 \%$ hanya 5 orang dari 21 siswa.

2. Metode pembelajaran yang digunakan membosankan

3. Tidak adanya media pendukung dalam proses pembelajaran sehingga siswa merasa jenuh.

4. Kurangnya motivasi yang diberikan oleh guru sehingga siswa menjadi tidak bersemangat

5. Guru hanya melakukan komunikasi satu arah sehingga tidak terciptanya umpan balik antara guru dan siswa yang menyebabkan siswa pada akhirnya tidak merespon materi yang diajarkan guru. 
Penulis juga membuat beberapa instrumen yang digunakan penulis sebagai tolak ukur dalam melakukan perbaikan proses pembelajaran. Instrumen tersebut adalah :

1. Instrumen Pengamatan untuk mengetahui hasil belajar dari peserta didik.

2. Instrumen pengamatan peserta didik yang dapat menjawab dan tidak dapat menjawab pertanyaan dari guru.

3. Lembar evaluasi tiap - tiap siklus dengan menulis rata - rata kelas.

1. Prasiklus

Pada pembelajaran prasiklus, nilai tertinggi adalah 90 dan nilai terendah adalah 30 dengan nilai rata - rata kelas 55,95. Peserta didik yang tuntas dalam belajar hanya berjumlah 5 peserta didik dari 21 peserta didik atau sekitar $24 \%$.Peserta didik yang belum tuntas berjumlah 16 peserta didik dari 21 peserta didik atau sekitar 76\% (hal ini tergambar pada tabel 2). Berdasarkan hasil pengamatan yang dilakukan penulis pada proses pembelajaran terhadap peserta didik yang mampu menjawab pertanyaan hanya 7 peserta didik dari jumlah 21 peserta didik atau sekitar 33\%. Sedangkan peserta didik yang tidak mampu menjawab pertanyaan ada 14 peserta didik dari jumlah 21 peserta didik atau sekitar $67 \%$

\section{Siklus 1}

Pada pembelajaran siklus 1, penulis menggunakan model pembelajaran Contextual Teaching Learning (CTL ) dengan bantuan media gambar. Terdapat peningkatan hasil belajar peserta didik, tetapi hasil belajar rata - rata kelas peserta didik masih dibawah nilai KKM.

Ada beberapa masalah yang dicatat oleh penulis dari kegiatan pembelajaran siklus 1, yaitu :

1. Masih adanya peserta didik yang terlihat kurang motivasi dalam belajar.

2. Masih banyak peserta didik yang nilainya di bawah nilai KKM.

3. Masih banyak siswa yang belum terlibat aktif dalam prose kegiatan pembelajaran.

4. Media pembelajaran yang digunakan belum mampu membangkitkan kreatifitas siswa dalam menjawab pertanyaan yang dilontarkan guru.

Pada Siklus 1 diperoleh total nilai 450, nilai tertinggi yang dicapai pada siklus 1 sebesar 100 dan nilai terendah 40 dan rata-rata 69,0. 
Sedangkan Hasil pengamatan yang dapat menjawab salah 8 atau 38\% dan yang dapat menjawab dengan benar 13 atau $62 \%$

\section{Siklus 2}

Pada siklus 2, nilai tertinggi adalah 100 dan nilai terendah adalah 70 dengan rata- rata kelas peserta didik sebesar 89,52 Peserta didik yang tuntas dalam belajarnya sebesar 17 orang dari 21 peserta didik atau $81 \%$ dan yang belum tuntas sebanyak 4 orang dari 21 peserta didik atau 19\%. Adapun hasil pengamatan terhadap peserta didik yang mampu menjawab pertanyaan adalah sebesar 17 orang dari 21 peserta didikatau sekitar $.81 \%$ dan yang belum bisa menjawab adalah sekitar4 orang dari 21 peserta didik atau sekitar $19 \%$.

Setelah penulis mengadakan perbaikan secara berulang akhirnya dapat disajikan tabel rekapitulasi nilai hasil belajar dan pengamatan terhadap peserta didik yang mampu menjawab dan tidak mampu menjawab pertanyaan. Pada Prasiklus nilai tertinggi adalah 90 dan nilai terendah adalah 40 dengan rata -rata kelas sebesar 55,95 dan tingkat ketuntasan sebesar 24\%.. Mengalami Kenaikan pada siklus 2 nilai tertinggi 100 dan Nilai terendah 40 dengan rata - rata kelas sebesar 69,01 dan tingkat ketuntasan sebesar 52\%. Kembali mengalami kenaikan pada siklus 2,kali ini terlihat cukup signifikan jika kita melihat dari perolehan di tahap Prasiklus dimana Nilai tertinggi adalah 100 dan terendah 70 dengan rata rata kelas sebesar 86,67 serta tingkat ketuntasan sebesar 81\%. Dalam hasil pengamatan guru terhadap siswa yang mampu menjawab dan tidak mampu menjawab pertanyaan guru juga terlihat mengalami kenaikan. Pada tahap Prasiklus prosentase siswa yang mampu menjawab sebesar 5\%,kemudian terjadi peningkatan sebesar $62 \%$ pada siklus 1 dan kembali mengalami peningkatan sebesar $81 \%$ di siklus 2 .

Berikut penulis sajikan Rekapitulasi Nilai hasil belajar peserta didik (tabel 8) dan rekapitulasi pengamatan peserta didik (Tabel 9) yang terjadi pada masing masing tahap yaitu prasiklus,siklus1 siklus 2 
Tabel 8

Data Rekapitulasi Nilai Hasil Belajar Matematika

\begin{tabular}{|c|c|c|c|c|c|}
\hline No & Nama & $\mathbf{L} / \mathbf{P}$ & $\begin{array}{c}\text { Prasiklu } \\
\text { s }\end{array}$ & Siklus 1 & Siklus 2 \\
\hline 1 & Alia amelia & $\mathrm{P}$ & 50 & 50 & 80 \\
\hline 2 & Anindra Aqilla $\mathrm{R}$ & $\mathrm{L}$ & 30 & 50 & 70 \\
\hline 3 & Audiva Nayla R & $\mathrm{P}$ & 50 & 80 & 100 \\
\hline 4 & Callysta Valda Y & $\mathrm{P}$ & 40 & 45 & 75 \\
\hline 5 & Dhiyaul Arkan & $\mathrm{L}$ & 30 & 90 & 100 \\
\hline 6 & Gulamia Zaid Syaira & $\mathrm{P}$ & 40 & 65 & 85 \\
\hline 7 & Fachrudin ismail & $\mathrm{L}$ & 60 & 80 & 100 \\
\hline 8 & Fauziah karimah A & $\mathrm{P}$ & 40 & 40 & 80 \\
\hline 9 & Iqbal Maulana $\mathrm{H}$ & $\mathrm{L}$ & 40 & 40 & 70 \\
\hline 10 & Kamila Dewi Y R & $\mathrm{P}$ & 60 & 60 & 100 \\
\hline 11 & Kemal Hibatillah Z & $\mathrm{L}$ & 90 & 80 & 100 \\
\hline 12 & Miqdad Ramadhan & $\mathrm{L}$ & 60 & 100 & 70 \\
\hline 13 & Muhammad Azka L & $\mathrm{L}$ & 80 & 70 & 100 \\
\hline 14 & Muhammad Rafly A & $\mathrm{L}$ & 80 & 90 & 90 \\
\hline 15 & Muhammad Naufal & $\mathrm{L}$ & 75 & 90 & 100 \\
\hline 16 & Rafa Almeyda P & $\mathrm{L}$ & 50 & 90 & 70 \\
\hline 17 & Siti Azizah Amanah & $\mathrm{P}$ & 50 & 50 & 80 \\
\hline 18 & Stania Amanda K & $\mathrm{P}$ & 60 & 80 & 90 \\
\hline 19 & Ubaydillah Sidiq P & $\mathrm{L}$ & 40 & 40 & 80 \\
\hline 20 & Yasmine Khalila I & $\mathrm{P}$ & 70 & 80 & 90 \\
\hline 21 & Zahra & $\mathrm{P}$ & 80 & 80 & 90 \\
\hline \multicolumn{3}{|c|}{ Total Nilai } & 1175 & 1450 & 1820 \\
\hline \multicolumn{3}{|c|}{ Rata - Rata } & 55,95 & 69,01 & 86,67 \\
\hline \multicolumn{3}{|c|}{ KKM } & 75 & 75 & 75 \\
\hline \multicolumn{3}{|c|}{ Nilai Tertinggi } & 90 & 100 & 100 \\
\hline \multicolumn{3}{|c|}{ Nilai Terendah } & 40 & 40 & 70 \\
\hline \multicolumn{3}{|c|}{ Ketuntasan } & $24 \%$ & $52 \%$ & $81 \%$ \\
\hline
\end{tabular}

Tabel 9

Data Rekapitulasi Pengamatan Hasil Belajar

\begin{tabular}{|c|l|c|c|c|c|c|c|c|}
\hline \multirow{2}{*}{ No } & \multirow{2}{*}{ Nama } & \multirow{2}{*}{ L/P } & \multicolumn{2}{|c|}{ Prasiklus } & \multicolumn{2}{c|}{ Siklus 1 } & \multicolumn{2}{c|}{ Siklus 2 } \\
\cline { 4 - 9 } & & & M & TM & M & TM & M & TM \\
\hline 1 & Alia amelia & P & & $\sqrt{ }$ & & $\sqrt{ }$ & $\sqrt{ }$ & \\
\hline 2 & Anindra Aqilla & L & & $\sqrt{ }$ & & $\sqrt{ }$ & & $\sqrt{ }$ \\
\hline
\end{tabular}




\begin{tabular}{|c|c|c|c|c|c|c|c|c|}
\hline 3 & Audiva Nayla R & $\mathrm{P}$ & & $\sqrt{ }$ & $\sqrt{ }$ & & $\sqrt{ }$ & \\
\hline 4 & Callysta Valda & $\mathrm{P}$ & & $\sqrt{ }$ & & $\sqrt{ }$ & $\sqrt{ }$ & \\
\hline 5 & Dhiyaul Arkan & $\mathrm{L}$ & & $\sqrt{ }$ & $\sqrt{ }$ & & $\sqrt{ }$ & \\
\hline 6 & Gulamia Zaid S & $\mathrm{P}$ & & $\sqrt{ }$ & & $\sqrt{ }$ & $\sqrt{ }$ & \\
\hline 7 & Fachrudin I & $\mathrm{L}$ & & $\sqrt{ }$ & $\sqrt{ }$ & & $\sqrt{ }$ & \\
\hline 8 & Fauziah & $\mathrm{P}$ & & $\sqrt{ }$ & & $\sqrt{ }$ & $\sqrt{ }$ & \\
\hline 9 & Iqbal Maulana & $\mathrm{L}$ & & $\sqrt{ }$ & & $\sqrt{ }$ & & $\sqrt{ }$ \\
\hline 10 & Kamila Dewi Y & $\mathrm{P}$ & $\sqrt{ }$ & & $\sqrt{ }$ & & $\sqrt{ }$ & \\
\hline 11 & Kemal H Zidane & $\mathrm{L}$ & $\sqrt{ }$ & . & $\sqrt{ }$ & & $\sqrt{ }$ & \\
\hline 12 & Miqdad R & $\mathrm{L}$ & & $\sqrt{ }$ & & $\sqrt{ }$ & $\sqrt{ }$ & $\sqrt{ }$ \\
\hline 13 & M Azka LZ & $\mathrm{L}$ & $\sqrt{ }$ & & $\sqrt{ }$ & & $\sqrt{ }$ & \\
\hline 14 & M.Rafly A & $\mathrm{L}$ & $\sqrt{ }$ & & $\sqrt{ }$ & & $\sqrt{ }$ & \\
\hline 15 & M.Naufal A & $\mathrm{L}$ & $\sqrt{ }$ & & $\sqrt{ }$ & & $\sqrt{ }$ & \\
\hline 16 & Rafa Almeyda & $\mathrm{L}$ & & $\sqrt{ }$ & $\sqrt{ }$ & & $\sqrt{ }$ & \\
\hline 17 & Siti Azizah A & $\mathrm{P}$ & & $\sqrt{ }$ & $\sqrt{ }$ & & $\sqrt{ }$ & \\
\hline 18 & Stania Amanda & $\mathrm{P}$ & & $\sqrt{ }$ & $\sqrt{ }$ & & $\sqrt{ }$ & \\
\hline 19 & Ubaydillah S P & $\mathrm{L}$ & & $\sqrt{ }$ & & $\sqrt{ }$ & & $\sqrt{ }$ \\
\hline 20 & Yasmine & $\mathrm{P}$ & $\sqrt{ }$ & & $\sqrt{ }$ & & $\sqrt{ }$ & \\
\hline 21 & Zahra & $\mathrm{P}$ & $\sqrt{ }$ & & $\sqrt{ }$ & & $\sqrt{ }$ & \\
\hline \multicolumn{3}{|c|}{ Jumlah } & 7 & 14 & 13 & 8 & 17 & 4 \\
\hline \multirow{2}{*}{\multicolumn{3}{|c|}{ Prosentase }} & $5 \%$ & $95 \%$ & 62 & 38 & 81 & 19 \\
\hline & & & & & $\%$ & $\%$ & $\%$ & $\%$ \\
\hline
\end{tabular}

\section{B. Pembahasan Hasil Penelitian Perbaikan Pembelajaran}

Berdasarkan hasil observasi, refleksi dan diskusi dengan teman sejawat, terdapat perbaikan hasil yang terlihat cukup signifikan terhadap nilai yang diperoleh siswa kelas VI SDIT Taman Ilmu setelah penulis melakukan perbaikan pembelajaran.

Pada pembelajaran yang terjadi di tahap prasiklus, metode yang digunakan penulis yaitu metode ceramah. Hasil evaluasi peserta didik yang diukur dengan penilaian menunjukan nilai dibawah KKM dengan nilai rata rata 55,95 dengan hasil ketuntasan hanya $24 \%$ dan hanya $5 \%$ peserta didik yang dapat menjawab pertanyaan dari guru. Pada siklus 1, penulis menggunakan model pembelajaran Contextual Teaching Learning (CTL) dan media berupa gambar. Hasil evaluasi peserta didik mengalami kemajuan dengan rata - rata kelas menjadi 69,01 dengan hasil ketuntasan sebesar 52\%. 
Dari hasil pengamatan penulis terhadap siswa yang mampu menjawab pertanyaan guru juga mengalami kenaikan yaitu sebesar $62 \%$. Meskipun mengalami kenaikan, Namun nilai rata - rata kelas peserta didik belum mencapai harapan atau masih di bawah KKM.Sehingga Penulis memandang perlu untuk melanjutkan perbaikan pembelajaran di siklus selanjutnya, yaitu siklus 2.

Perbaikan pembelajaran yang dilakukan selanjutnya terjadi pada siklus 2 . Pada siklus ini selain menggunakan gambar penulis juga menambahakan media berupa video pembelajran (Audiovisual) yang penulis ambil dari Youtube.Selain itu penulis juga memaksimalkan pengguanaan model pembelajaran Contextual Teaching Learning dengan banyak memancing dengan melontarkan pertanyaan yang "HOTS" agar siswa terpancing untuk menjawab pertanyaan yang dilontarkan. Terjadi peningkatan yang cukup signifikan terhadap hasil belajar peserta didik. Hal ini ditandai dengan peningkatan hasil belajar peserta didik dengan nilai rata - rata 86,67 dan prosentase ketuntasan sebesar $81 \%$. Adapun prosentase peserta didik yang mampu menjawab pertanyaan yang diberikan sebesar $81 \%$.

Penerapan model pembelajaran Contextual Teaching Learning dengan menggunakan media pembelajaran berupa media gambar dan media Audiovisual memberikan pengaruh yang sangat positif pada hasil belajar peserta didik. Penggunaan model ini juga dapat membangun kreativitas dan keaktifan peserta didik pada proses pembelajaran.

\section{V.SIMPULAN DAN SARAN TINDAK LANJUT}

A. Simpulan

Dari hasil penelitian perbaikan pembelajaran yang dilakukan oleh penulis ada beberapa hal yang dapat disimpulkan :

1. Pada hasil pembelajran yang terjadi di tahap prasklus dengan nilai KKM yang telah ditetapkan sebelumnya sebesar 75 , terdapat hanya 5 peserta didik yang tuntas dari jumlah 21 peserta didik atau sebesar 24\%. Pada Siklus 1 terjadi kenaikan peserta didik yang tuntas menjadi 11 orang dari jumlah 
peserta didik sebanyak 21 orang atau sebesar 52\%, dimana nilai tertinggi 100 dan Nilai terendah 40 dengan rata - rata kelas sebesar 69,01.Pada Siklus 2 kembali mengalami kenaikan ,kali ini terlihat cukup signifikan jika kita melihat dari perolehan di tahap prasiklus dimana Nilai tertinggi adalah 100 dan terendah 70 dengan rata-rata kelas sebesar 86,67 serta tingkat ketuntasan sebesar $81 \%$ atau terdapat 17 orang peserta didik yang tuntas dari jumlah peserta didik 21 orang.Dalam hasil pengamatan guru terhadap siswa yang mampu menjawab dan tidak mampu menjawab pertanyaan guru juga terlihat mengalami kenaikan. Pada tahap Prasiklus prosentase siswa yang mampu menjawab sebesar 5\%,kemudian terjadi peningkatan sebesar $62 \%$ pada siklus 1 dan kembali mengalami peningkatan sebesar $81 \%$ di siklus 2

2. Penerapan model pembelajaran Contextual Teaching Learning dengan bantuan media gambar dan Audiovisual sangat membantu guru dan peserta didik dalam proses pembelajaran karena proses tersebut telah mampu membangun minat dan motivasi siswa sehingga siswa terlihat lebih aktif dan kreatif dalam pelaksanaan proses pembelajaran yang terjadi pada mata pelajaran IPA tema Ciri Khusus Tumbuhan dan makhluk hidup.

B. Saran dan Tindak Lanjut

Berdasrkan kesimpulan diatas maka penulis menyarankan agar guru :

1. Selalu melakukan refleksi terhadap proses pembelajaran yang dilakukan,hal ini bertujuan agar guru dapat mngetahui kelemahan dan kekuatan yang kemudian menjadi acuan untuk melakukan perbaikan pembelajaran

2. Keberadaan rekan kerja selaku teman sejawat dapat dioptimalkan keberadaannya untuk memberi kritik dan saran kepada guru tentang proses pembelajaran.

3. Selalu membangun komunikasi yang baik tidak hanya pada rekan sejawat tapi juga bisa kepada orang yang ahli dibidangnya agar dapat memberikan masukan tentang proses pembelajaran yang akan atau telah dilaksanakan

4. Dapat terbuka menerima kemajuan dan perkembangan Informasi dan Tekhnologi dan selalu berusaha mengembangkan diri agar menjadi guru yang profesional di bidangnya. 
5. Selalu membangun komunikasi2 arah yang efektif antara guru dan siswa sehingga siswa menjadi terpancing untuk menemukan jawaban terhadap sebuah pertanyaan.

6. Selalu dapat memotivasi peserta didik agar menjadi semangat,aktif dan kreatif sehingga proses pembelajaran menjadi hidup karena semua komponen yang terlibat menjadi aktif serta kreatif.

7. Selalu berinovasi dengan berbagai model pembelajaran sehingga peserta didik tidak merasa jenuh dengan cara guru mengajar.

\section{DAFTAR PUSTAKA}

Sapriati, Amalia, (2009). Pembelajaran IPA di SD. Jakarta: Universitas Terbuka.

Jufri, A. Wahab, (2017). Belajar dan Pembelajaran Sains :Modal dasar menjadi Guru profesional. Bandung : Pustaka Reka Cipta.

Suryanto, Adi, (2016) Evaluasi Pemeblajaran di SD. Tanggerang Selatan: Universitas Terbuka.

Suprihatin, Y., \& Sulfemi, Wahyu Bagja. (2013). Kemampuan Menulis Deskripsi. Bogor: STKIP Muhammadiyah Bogor.

Sulfemi, Wahyu Bagja. (2016). Modul Pembelajaran Ilmu Sosial dan Budaya Dasar. Bogor : STKIP Muhammadiyah Bogor

Sulfemi, Wahyu Bagja. (2009). Modul Pembelajaran Pendidikan Pancasila dan Kewarganegaraan. Bogor: STKIP Muhammadiyah Bogor. 1. 1-49.

Anitah W, Sri dkk, (2014). Strategi Pembelajaran di SD.Tangerang Selatan: Universitas Terbuka.

Sanjaya, H. Wina. (2016). Strategi pembelajaran Berorientasi Standar Proses Pendidikan Jakarta: Prenadamedia Group.

Sulfemi, W. B. (2018). Pengaruh Disiplin Ibadah Sholat, Lingkungan Sekolah, dan Intelegensi Terhadap Hasil Belajar Peserta Didik Mata Pelajaran Pendidikan Agama Islam. EDUKASI: Jurnal Penelitian Pendidikan Agama dan Keagamaan, 16(2).

Sulfemi, Wahyu Bagja. (2018). Manajemen Kurikulum di Sekolah. Bogor : Visi Nusantara Maju

Sulfemi, Wahyu Bagja \& Desmiati, Z. (2018). Model Pembelajaran Missouri Mathematics Project Berbantu Media Relief Experience dalam Meningkatkan Hasil Belajar Siswa. Pendas Mahakam: Jurnal Pendidikan Dasar, 3(3), 232-245. 
Sulfemi, Wahyu Bagja dan Minati, Hilga. (2018). Meningkatkan Hasil Belajar Peserta Didik Kelas 3 SD Menggunakan Model Picture And Picture dan Media Gambar Seri. JPSD. 4 (2), 228- 242.

Sulfemi, Wahyu Bagja \& Nurhasanah. (2018). Penggunaan Metode Demontrasi Dan Media Audio Visual Dalam Meningkatkan Hasil Belajar Peserta Didik Mata Pelajaran IPS. Pendas Mahakam: Jurnal Pendidikan Dasar, 3(2), $151-158$

Sulfemi, Wahyu Bagja dan Setianingsih. (2018), Penggunaan Tames Games Tournament (TGT) Dengan Media Kartu Dalam Meningkatkan Hasil Belajar. Journal of Komodo Science Education (JKSE. 1 (1), 1-14.

Sulfemi, Wahyu Bagja \&, Nova Mayasari. (2019). Peranan Model Pembelajaran Value Clarification Technique Berbantuan Media Audio Visual Untuk Meningkatkan Hasil Belajar IPS. Jurnal Pendidikan 20 (1), 53-68.

Sulfemi, Wahyu Bagja \& Yuliana, D. (2019). Penerapan Model Pembelajaran Discovery Learning Meningkatkan Motivasi Dan Hasil Belajar Pendidikan Kewarganegaraan. Jurnal Rontal Keilmuan Pancasila dan Kewarganegaraan, 5(1), 17-30

Sulfemi, Wahyu Bagja. (2019). Manajemen Pendidikan Berbasis Multi Budaya. Bogor : STKIP Muhammadiyah Bogor.

Sulfemi, W. B. (2019). Model Pembelajaran Kooperatif Mind Mapping Berbantu Audio Visual Dalam Meningkatkan Minat, Motivasi dan Hasil Belajar IPS. Jurnal PIPSI (Jurnal Pendidikan IPS Indonesia), 4(1), 13-19.

Sulfemi, W. B., \& Luthfianti, T. (2019). Asosiatif Layanan Tenaga Perpustakaan Sekolah dengan Motivasi Membaca Siswa di Kabupaten Bogor. Edutecno, 19(2), 1-10.

Sulfemi, Wahyu Bagja.(2019). Bergaul Tanpa Harus Menyakiti. Bogor : Visi Nusantara Maju.

Sulfemi, Wahyu Bagja. (2019). Menanggulangi Prilaku Bullying Di Sekolah. Bogor : Visi Nusantara Maju.

Sulfemi, Wahyu Bagja dan Yuliani, Nunung. (2019). Model Pembelajaran Contextual Teaching And Learning (CTL) Berbantu Media Miniatur Lingkungan Untuk Meningkatkan Hasil Belajar IPS. Edunomic : Jurnal Ilmiah Pendidikan Ekonomi Fakultas Keguruan Dan Ilmu Pendidikan. 7 (2) . 73-84.

Sulfemi, Wahyu Bagja (2019). Modul Pembelajaran Perundang-Undangan Pendidikan. Bogor : STKIP Muhammadiyah Bogor

Aqib, Zainal dan Ali Murtadlo, (2016) Kumpulan Metode Pembelajaran Kreatif dan Inovatif. Bandung : Sarana Tutorial Nurani Sejahtera

Arsyad,Azahra, (2014) Media Pembelajaran. Jakarta : Rajawali Pers 
Johnson, B.Elaine, (2007). Contextual Teaching \& Learning Menjadikan Kegiatan Belajar - Mengajar Mengasyikan dan Bermakna. Bandung : Mizan Learning Center

Yusfiriadi, Yusfiriadi, \& Sulfemi, Wahyu Bagja. (2012). Penyelewangan Dana Dalam Dunia Pendidikan. Fascho 1 (1), 1-9. 